\title{
Assessing Walkability of Planned and Historical Streetscape of Urban Dhaka
}

\author{
Farzana Siddiqua, SaimumKabir, Mania Tahsina Taher*
}

\begin{abstract}
Urban mobility is one of the pressing challenges Dhaka City facing today. Existing car based mobility network has already proven ineffective and thus leads to congestion, inequity and unhealthy urban environment. Even though largest portion of city population travels by walk, pedestrian mobility has been severely compromised especially in newly planned residential areas. Streets here are planned considering automobile as a primary mode of transport; a comfortable setting of walkable streets is almost nonexistent. However, the historic core of the city is an exception where streets are seen dominated by the pedestrian. The paper presents a comparative study of the walkability between planned (Bashundhara R/A) and historic (Shakhari bazar) urban area while taking into account the importance of active mobility for a healthy urban development. The study starts with reviewing theoretical constructs of 'pedestrian-friendly community development' while looking into case studies and urban standards in order to synthesize 'walkability' matrices. Multiple tools are used to measure walkability of the street. Maps are studied to analyze the physical context of selected urban area, scientific tools are used to collect site specific microclimatic data, observation and questionnaire surveys are conducted to understand user's response. The aim is to formulate a checklist of walkable streetscape in the context of Dhaka, Bangladesh. The study identifies the physical (height width ratio, vegetation, water features, orientation) and functional attributes (location of amenities, infrastructure, safety) of street fabric has strong impact on improving walkability.
\end{abstract}

Keywords-Urban sprawl; Urban Mobility; Walkability; Active Mobility; Pedestrian-friendly Community Development;

\section{INTRODUCTION}

This Walkability is one of the prime concerns of the recent day's urban researchers, when they are in consideration to draw out the parameters of urban mobility in case of any urban context that works for the wellbeing of people. If we talk about our cities and their walkability, then we should consider the factor that the world's urban areas are growing very fast in terms of population and infrastructure, which would bring

\section{Farzana Siddiqua}

Lecturer, American International University - Bangladesh (AIUB)

Dhaka, Bangladesh

e-mail: farzana_7@aiub.edu

\section{Saimum Kabir}

Assistant Professor, American International University - Bangladesh (AIUB) Dhaka, Bangladesh

e-mail: saimum@aiub.edu significant change in the city fabric and environments in near future. In fact, according to UN DESA (2010), 69\% of world's population is assumed to migrate to the urban areas by 2050 . [1] The major problem for attaining walkable city environment by the fast growing cities is the unplanned urban sprawl, which is escorted by several inter-linked urban problems, likeinefficient land use, car dominated neighborhood, traffic congestion, high carbon emission, segregation of functions and uses etc. Urban researchers have always affirmed on pedestrian than car-driven urbanism- 'walkable neighborhood' is a key factor to promote a healthy living, according to urban researcher Emily Talen. [2] Physical infrastructure such as paths and streets are considered as the basic element that played a critical role in developing a community by connecting space, people and nature and thereby facilitated social interaction, commerce and mobility. "Hence a 'walkable' community provides an affordable, comfortable and healthy socio-physical structure in order to live and work, along with enhancing towards a sustainable environment". [3]

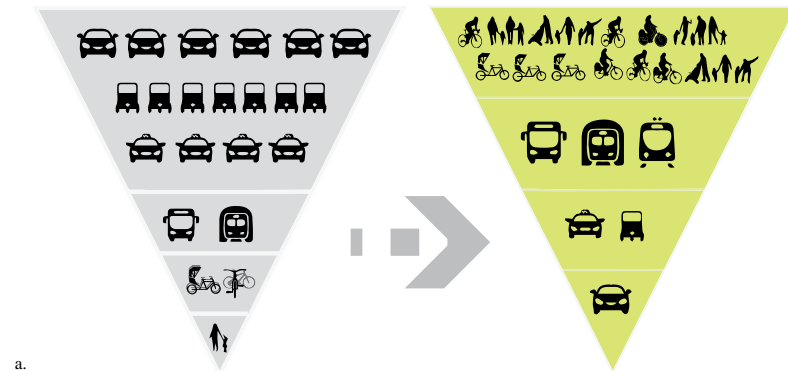

Fig. 1. Diagram expressing importance of transforming streets and it's vehicles for attaining sustainable communities

In this research paper, we are considering our urban context of Dhaka, Bangladesh; and investigating the walkability of the present and future developments of the city neighborhoods. In this process, we are also making comparison of the new urban fabric to the old, and, have chosen two different locations from the city as case studies- the historical (Shakhari bazar), and the new part (Bashundhara R/A) of Dhaka. Dhaka's historical urban fabric located to the south part of the city was organically developed before motorized vehicle-era, and formed pedestrian-dominated neighborhoods. On the other hand, the newer developments grown from 1950's till today have faced most recent significant change of land use over the last few decades, and the road networks have been designed to become motor vehicle-friendly. Considering future expansion of the city, strategic transport plans are conceived but in

Mania Tahsina Taher

Assistant Professor, American International University - Bangladesh (AIUB) Dhaka, Bangladesh

e-mail: maniataher@aiub.edu 
execution priority has been given to major interventions of city road system including flyovers and elevated expressway, by 2025 .

\section{Context}

In the course of history, Dhaka has expanded from a medieval trading town to modern metropolis- at present, one of the densely populated cities of the world where 18 million people live on 360 square kilometers of Dhaka metropolitan area. [4] The city started on the bank of Buriganga River, and the development advanced toward the north. In future, an unplanned growth is predicted over the farm lands towards the east, bounded by Balu River; north and west of the city is also surrounded by Turag River. Throughout the year, Dhaka experiences hot and humid climate due to its sub-tropical location. The daily average maximum temperature of Dhaka is $250 \mathrm{C}$, and the average minimum is $100 \mathrm{C}$; during the month of June which is the summer season, the average maximum is $32^{\circ} \mathrm{C}$ and the average minimum of $25^{\circ} \mathrm{C}$. [4]

Dhaka has faced strong changes in the characteristics of transportation system in its later development phases, and since then, the city has become more favorable to vehicle transportation system, even for short-term distances. [5] Nonmotorized vehicle (rickshaw) has also played an important role in the city's transportation for short-distance travelling, but due to the excessive presence of both motorized and non-motorized vehicles in most of the streets lacking separate ways, there is always traffic congestion in the streets. According to the survey report of Urban Transport Network Development Study (DHUTS), 2010, Figure 1 shows that in Dhaka Metropolitan area (DMA), $37.20 \%$ of street made by pedestrian which is highest and then $28.50 \%$ of streets is made by rickshaw (nonmotorized Transport, NMT). [6]

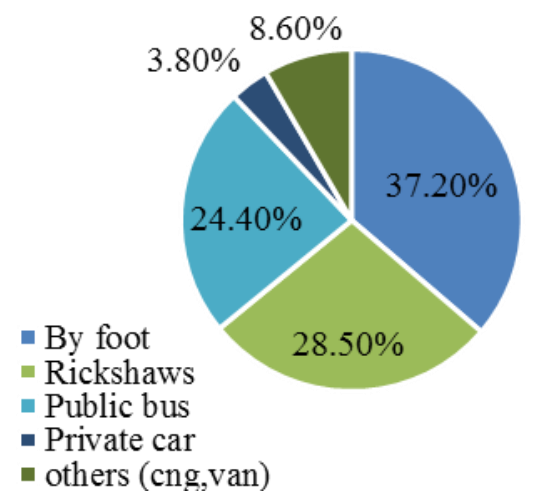

Fig. 2. Vehicle mode percentage at the streets of Dhaka Metropolitan Area (DMA)

On the other hand, the transportation data statistics of Dhaka City Corporation (DCC) is found even poorer in comparison to that of Dhaka Metropolitan Area (DMA), especially regarding pedestrian streets. The percentage of the pedestrian street is not the majority in the survey; rather it constitutes only $19 \%$, and it states that, the majority vehicle that plays on the Dhaka streets is rickshaw which is $38.70 \%$, and then DCC-run public bus comes second, at only $28.5 \%$. According to the survey, non-motorized vehicle (rickshaw) has always played an important role in DCC area's transport system. Another survey quantified the pedestrian mode share in different Asian countries in different time lines, and stated that the mode shade of walking is significant in Dhaka, and it was
$62 \%$ in 1999 [7]. On the contrary, a global status report on road safety by World Health organization (WHO), 2009, stated that "Pedestrian fatality share" of road accident among the Asian countries Bangladesh is in the 2nd highest of accident $54 \%$. They also mentioned reservations about discontinuity of pedestrian footpaths on both sides of city roads and neighborhood streets, poor crossing, pedestrian encroachment by illegal hawkers and shops, lack of disable access etc.

\section{RESEARCH QUESTIONS AND OBJECTIVES}

The current study is perhaps an attempt to lessen the gap between theory and practice by formulating design guidelines appropriate for subtropical city like Dhaka. The specific inquiries are: what type of streetscape influences the walkability of urban street of Dhaka? Does historical streetscape offers better pedestrian environment? If so, then what are the street features that can be integrated in planning and design practice of residential neighborhood?

Main objective of this study is to formulate a checklist for designing a pedestrian friendly streetscape for urban neighborhood of Dhaka.

\section{LITERATURE REVIEW}

This literature review affords to find out concurrent knowledge stock on the stated research agenda and speculative support to structure the research. The study focuses on theoretical discourses and relevant case studies both at local and international context. In order to sustenance the research by addressing research question, the correlation among walkability of street fabric in respect to new and historic neighborhood morphology has been thoroughly reviewed.

Rapid and uncontrolled growth pattern of Dhaka city is the main challenge to a successful urban development and healthy neighborhood, especially in the newly planned residential areas where a setting of walkable streets is almost nonexistent. Perhaps, walkable or pedestrian-friendly streets used to be fundamental elements to ensure a good urban life and encourage good health and wellbeing of humans. In order to study the state of walkability in the context of Dhaka, the attributes that have been studied mostly are- city street pattern and connectivity, geometry of street canyon, mixed-use and density, amenities and infrastructures, safety, and, comfort sensation of the pedestrian. This review ascertains that gridpatterned, automobile dominated newly planned residential developments are facing problems from pedestrian nonconnectivity, and turning into unhealthy communal neighborhoods. It is also revealed that the geometry of urban canyon influences the street level for pedestrian activity.

\section{A. Walkability and Neighborhood}

According to USA's Walkable Community Inc., the statement of a walkable neighborhood is, "Walkable communities put urban environments back on a scale for sustainability of resources (both natural and economic) and lead to more social interaction, physical fitness and diminished crime and other social problems". [8] The organization conducted a brief research, and, the research initially used survey data comprised with telephone interview of elderly 698 peoples randomly sampled from a selected area, and also surveyed on socio-demographic, neighborhood participation, environment and walking behavior of that site. The research finally derived at some decisions which are- 
- Considering health issue for both in high-density residential area and low density area the threshold limit for travel distance lies between 860 feet to daily facilities and 1445 feet for super store facility.

- Interrogation of the theoretical concepts of neighborhoods centered on recreational center and educational facilities.

- The research preferred mixed use land pattern over suburban and small special units, for analyzing and intervening to promote walkability in the neighborhood

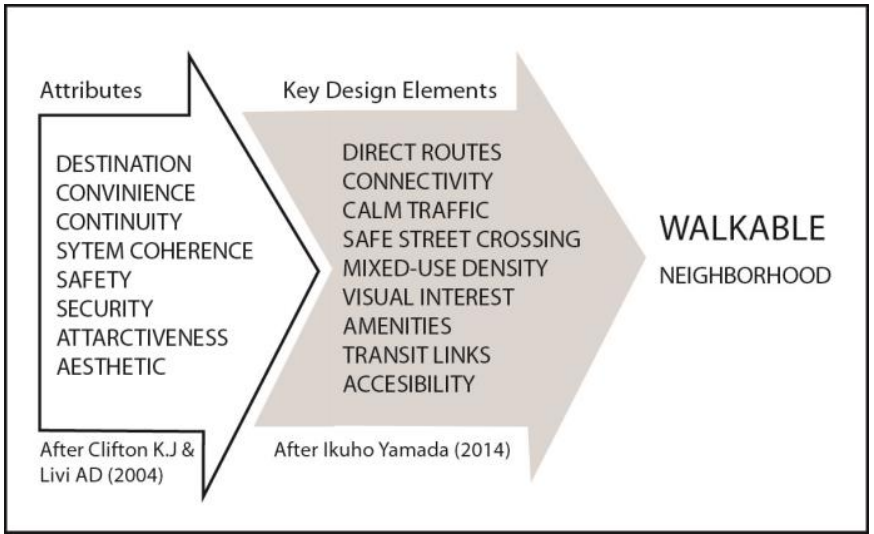

Fig. 3. Diagram showing attributes for measuring pedestrian 'friendliness' according to different academic studies. Source: Authors

\section{B. Street Fabric, Climate and Walkability}

Climate and the interface of built environment (urban fabric) are a two-way relationship. When climate influences urban development, then it results into a "microclimate" or a small surrounding that is different from the adjacent area [9]. According to Bekele et al, 2008, some influential urban street factors are an area's basic climatic condition, street orientation and width (H: W ratio), distribution of mass, density, shading, solar heat, anthropogenic heat, vegetation. For hot and humid climate main objective for designing are ventilating street, orientation and placement of building and vegetation. The positioning and type and canopy of the trees should be analyzed to get effective shades in summer and sun exposure in winter. The literature also recommends relatively narrow streets to promote air circulation where street-canyon ratio should be 0.7 or less. And also emphasizes to achieve "maximum shading" by vegetation which have significant affects at outdoor comfort. [10] Another study in the city of Brisbane, Australia, hot humid condition in urban context was studied, and noted that traditional buildings along the street was lined with awning, colonnaded, arcade features to provide sun shading. Some other buildings had verandah to which is partly enclosed can also provide shade on pedestrians [11]. There are also examples of tropical-climate urban contexts designed as pedestrian-friendly, like- Malaysia, Vietnam, Indonesia, Singapore and Thailand. In major urban metropolitan areas of these countries, the streetscape elements were designed to mitigate excessive temperature in order to prevent mean radiant temperature, and proposed some hybrid passive cooling system with purpose to accelerate evaporative and radiated cooling to ensure thermal comfort for pedestrians. Figure 4 shows that water features like water fountain, rain garden, mist fan etc. were installed alongside the pedestrian footpaths of major walking districts, to drive away excessive humidity [12].

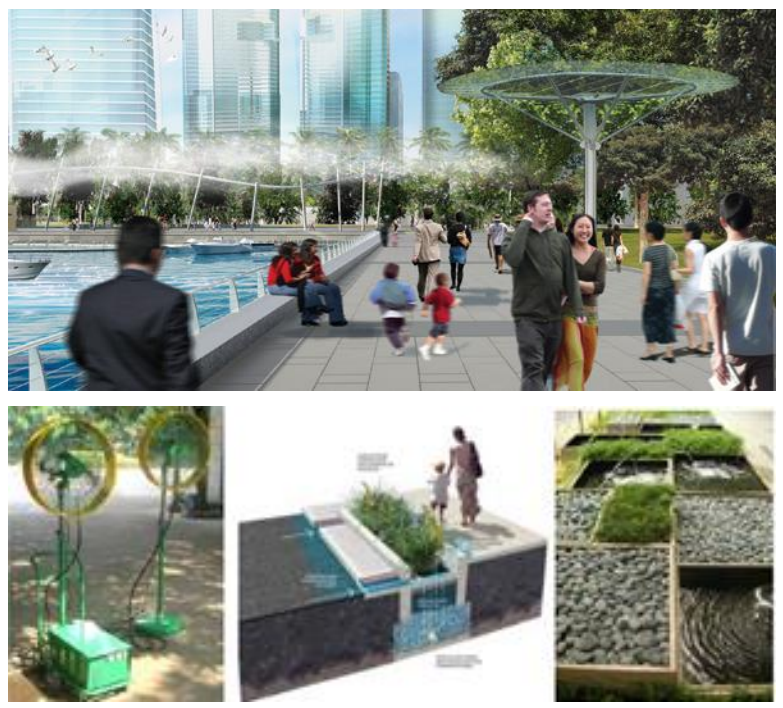

Fig. 4. Streetscape elements- water fountain, mist fan and rain garden installed to achieve passive cooling in tropical urban areas

A recent academic study investigating the impacts of FAR rules implemented by RAJUK on outdoor thermal comfort in the urban metropolitan areas of Dhaka revealed some interesting facts on the walkability scenario in overall. [13] The study focused on spatio-temporal characteristics of ambient climate, like- outdoor air temperature, surface temperature and wind speed condition in the urban hot-humid environment at street level. Random locations of different street orientation in the planned residential area of Dhaka city were studied using results from an intensive field survey including thermal imaging of canyon surfaces. Both the field data and computer based simulation results were analyzed and observed in terms of street canyon ratio to recommend possible guidelines for modification and adjustment of the FAR rules to enhance urban micro climate in residential areas. The findings and results of the analysis are- $1 . \mathrm{N}-\mathrm{S}$ street canyon is cooler than the E-W street canyon and the difference is around 0.9 to 0.2 . Deep street canyon (higher $\mathrm{H} / \mathrm{W}$ ratio) is preferable for N-S Street due to potential shade to reduce MRT (mean radiant temperature).

- Shallow street canyon (Lower H/W ratio) is preferable for E-W Street for wind ventilation at pedestrian level and low MRT due to setback.

- Plantation is suggested for the E-W street canyon to create shading to reduce MRT but not in N-S street canyon as they may obstruct the wind flow.

- At pedestrian level for better wind flow N-S canyon should not be staggered.

- Considering comfortable microclimate "Form Based Coding" should be combined in the Metropolitan Building Construction Rules (BCR) 2008 with FAR rules. 


\section{Methodology}

The study follows empirical method to compare walkability between selected streets of newly planned residential area (Bashundhara R/A) and historic settlement (Shakhari bazar) of urban Dhaka. Based on comprehensive review of recent literature, the study develops urban street attributes to measure walkability of a neighborhood. These attributes are grouped into three generic aspects of an urban street that is functional, physical and physiological (table-1). Here 'street fabric' is considered as a variable for 'walkability'.

TABLE I. Key AtTRIBUtes OF 'WALKABILITy OF URBAN StREets'

\begin{tabular}{|c|c|c|}
\hline Functional & Physical & Physiological \\
\hline Connectivity & H/W ratio & Thermal \\
\hline distance & orientation & Acoustic \\
\hline Amenities & Building typology & Visual \\
\hline Security and safety & Shaded street canyon & Olfactory \\
\hline & Vegetation & Hygienic comfort \\
\hline
\end{tabular}

Field surveys are conducted to map the street fabric and measure the microclimatic data related to comfort by observing and using scientific instruments. Local weather data is collected from Bangladesh Meteorological Department (BMD) and correspondingly questioner survey is undertaken to collect people's response regarding "walkability". Social, economic, political factors are not considered within the analysis.

\section{A. Study Area}

Shakhari Bazaar is a historic settlement located in the old Dhaka part, under South Dhaka City Corporation ward 72. At present, almost 10,000 people live here within 4.6 acres of area which makes it one of the highest density areas of the world. Shakhari bazar is a part of three significant streets which provided the foundation of urban development of Dhaka from the pre Mughal period (early 16th century).

The urban fabric of historical area is characterized as high density mixed-use land, typically comprising the outer part as commercial and retail shops and inner part as residential and manufacturing uses. The settlement grows organically in a complicated manner, along with a 300 meter long Street lined by shops, some shops still hold the traditional crafting at the ground level and upper levels are mostly residential. Usually with 3-5 storied building (recently some buildings are renovated to make it 4-6 storied), some of the buildings are 100-200 years old with few even older. There are over 100 buildings (covering 142 building lots) including several vacant lots. Linear buildings with thick brick wall and arcaded walk ways with some unique features of the adjacent streets remains remarkable vibrant and active. The organic road patterns often cut deep inside the urban block with some sharp turns ("goli" local term for narrow streets), and some few lines pass through residential area which intensify the unique fabric. [14]

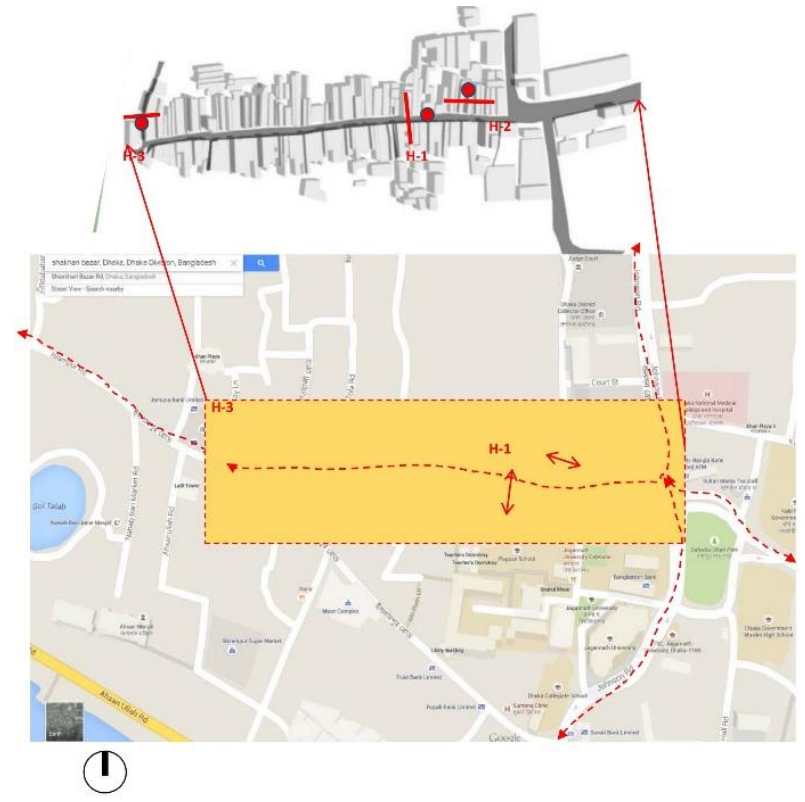

Fig. 5. Survey location Shakhari bazar, Dhaka, Bangladesh. (Source: Google map and location map detail by author)

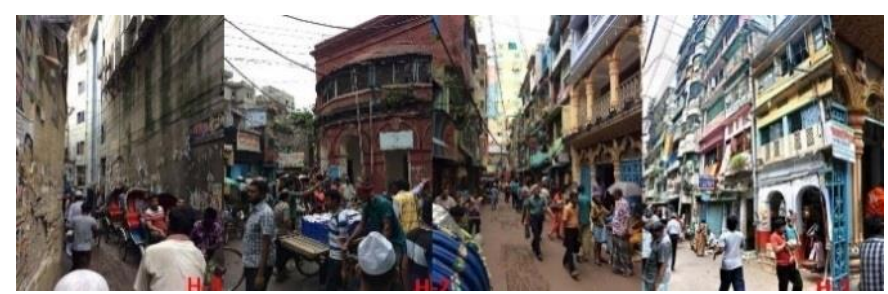

Fig. 6. Images showing pedestrian activities at Shakhari Bazaar, Old Dhaka (June, 2015); Source: Authors

Bashundhara Residential Area, is one of the largest private residential developments, falls under jurisdiction of Rajdhani Unnon Kortipokkho (RAJUK). The area is located into RAJUK Detail Area Plan (DAP) location -10, situated in the central eastern fringe of the city, and follow governments basic infrastructure, facilities and building rules. The population of RAJUK DAP-10 area was 2, 54,189 in 2001, and population growth has risen to $14,48,629$ in 2015- after successful implementation of Bashundhara. [15] The development started in 1987-88, and currently, total area is 19.74 sq.km with population density of 100 PPA. At present, only $25 \%$ of area development is considered to be completed. [16] The land use pattern is mostly residential area with some scattered located amenities according to the master plan.

Bashundhara is designed as grid road lay out, and the land area is divided mostly similar in size (rectangular) considering different plot option (3 katha, 5 katha, 10 katha). In this paper, the research area is concentrated at Block D (90 acre) and Block E (58 acre) area- considered for studying "road pattern" and "land use amenities". Three study streets have been selected from here for considering the study of orientation, hierarchy and amenities. At present, in block D and E (total 145 acre), study shows that only $20 \%$ of area is built, and only $7 \%$ of this area is dedicated to landscaping (green and water). $30 \%$ (46.6 acre) of study area is allotted to road network which follows street hierarchy of primary, secondary and tertiary road system. Except sidewalks no prominent pedestrian pathway or facilities regarding pedestrian involvement is considered in the overall master plan of Bashundhara, thus making this neighborhood as a pedestrian inactive area. 


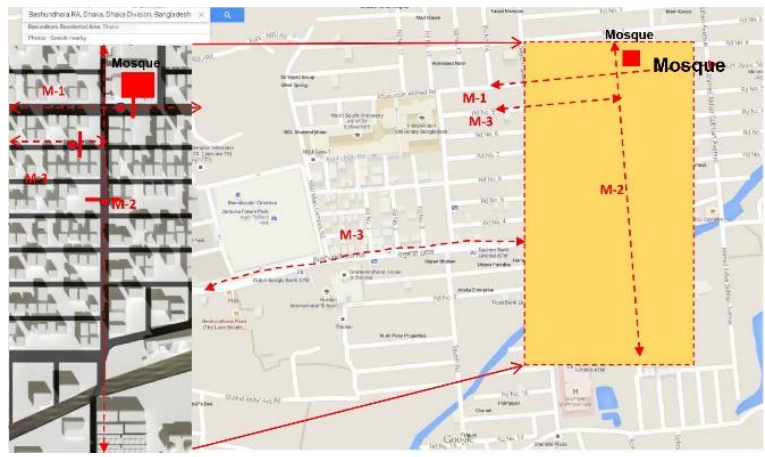

Fig. 7. Survey location Bashundhara R/A, Dhaka, Bangladesh. (Source: Google map and location map detail by author)

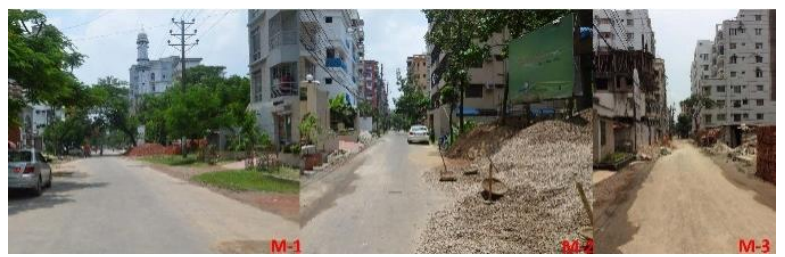

Fig. 8. Images showing pedestrian activities at Bashundhara R/A, New Dhaka (June, 2015) Source: Authors

\section{B. Survey process}

In order to collect information for research "field survey" is performed in 19th (weekend), 22nd and 23rd (week days) of June 2015 (one of the hottest season)at morning around 8:00 am, at noon around 12:00 pm and at afternoon around 5:00 pm.

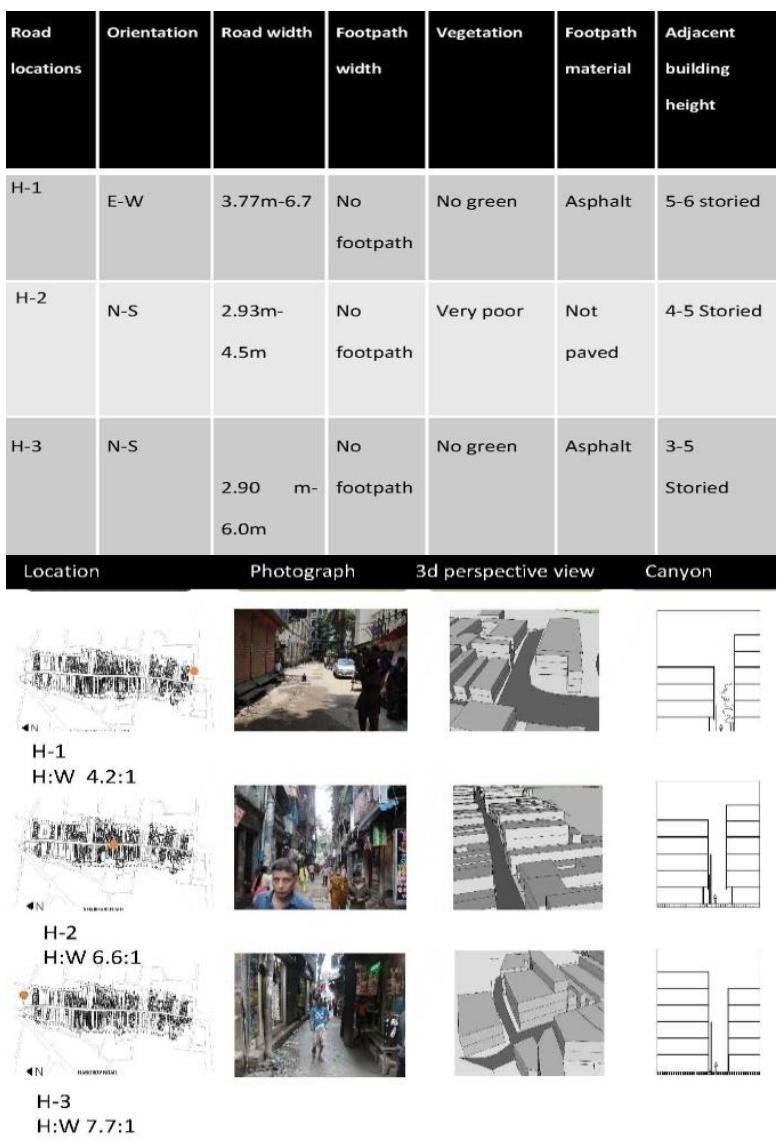

Fig. 9. Selected study streets, Shakhari bazar, Dhaka
Three study streets are selected in Banshundhara residential area (block C\&D) and historical area of Shakhari bazar road based on orientation and street hierarchy. Considering streets in north south $(\mathrm{N}-\mathrm{S})$ orientation and east west $(\mathrm{E}-\mathrm{W})$ orientation. In the historical area of Shakhari bazar, the selected streets are:

- H-1: Shakhari bazaar road (E-W)

- H-2: Court house street (branch road) (N-S),

- H-3: Noboray lane road (branch road) (N-S)

And, in Bashundhara, the selected streets are -

- M-1:Primary road (Mufti Abdur Rahman road) (E-W)

- M-2: Secondary road (Block D: Road -08) (N-S)

- $\quad$ M-3: Tertiary road (Block-D: Road-05) (E-W)

\section{RESULTS AND RECOMMENDATIONS}

Data analysis demonstrates that "street fabric" affect walkability of a neighborhood strongly. After analyzing the "street fabric" of the historical area (Shakhari Bazaar) and newly planned street of Dhaka, is it clear that the walkability condition of the historical street is more active as because of the compact, mixed-use urban fabric facilitated with amenities at close proximate, the narrow intricate pattern of the street, presence street features like arcade canopy and overhangs, place for sitting and resting, deep street canyon that provides mutual shading all together make the street comparatively comfortable and preferable for walking. On the other hand, the streets of planned residential area Bashundhara are found to be pedestrian inactive because of the disperse location of low density amenities, shallow street canyon, poorly maintained insufficient sidewalks and lack of street activity and shading features make the street comparatively uncomfortable and unpleasant to walk.

\begin{tabular}{|c|c|c|c|c|c|c|}
\hline $\begin{array}{c}\text { Road } \\
\text { locations }\end{array}$ & $\begin{array}{l}\text { Orient } \\
\text { ation }\end{array}$ & $\begin{array}{l}\text { Road } \\
\text { width }\end{array}$ & $\begin{array}{l}\text { Footpath } \\
\text { width }\end{array}$ & $\begin{array}{l}\text { Vegetatĩ } \\
\text { on }\end{array}$ & $\begin{array}{c}\text { Footpath } \\
\text { material }\end{array}$ & $\begin{array}{c}\text { Adjacent } \\
\text { building } \\
\text { height }\end{array}$ \\
\hline M-1 & $E-W$ & $\begin{array}{c}60^{\prime} \\
18.29 \\
m\end{array}$ & $\begin{array}{c}8-10^{\prime} \\
2.43 \mathrm{~m}- \\
3.04 \mathrm{~m}\end{array}$ & $\begin{array}{l}\text { Moder } \\
\text { ate }\end{array}$ & $\begin{array}{c}\text { Black } \\
\text { Asphalt }\end{array}$ & $\begin{array}{c}7-8+ \\
\text { storied }\end{array}$ \\
\hline$M-2$ & N-S & $\begin{array}{c}40^{\prime} \\
12.19 \\
2 \mathrm{~m}\end{array}$ & $\begin{array}{c}5^{\prime} \\
1.52 \mathrm{~m}\end{array}$ & $\begin{array}{l}\text { Moder } \\
\text { ate }\end{array}$ & $\begin{array}{c}\text { Black } \\
\text { Asphalt }\end{array}$ & $\begin{array}{c}6-7 \\
\text { Storied }\end{array}$ \\
\hline$M-3$ & $E-W$ & $\begin{array}{c}25^{\prime} \\
7.62 \\
m\end{array}$ & $\begin{array}{c}\text { No } \\
\text { footpath }\end{array}$ & low & $\begin{array}{c}\text { Black } \\
\text { Asphalt }\end{array}$ & $\begin{array}{c}5-6 \\
\text { Storied }\end{array}$ \\
\hline
\end{tabular}

Location Photograph 3d perspective view Canyon geometry

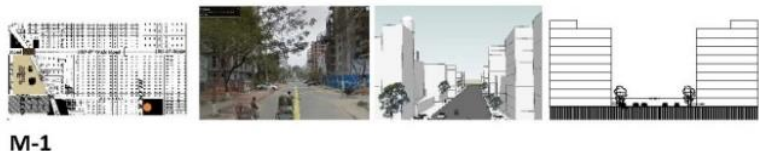

M-1

$\mathrm{H}:$ W $1: 1$

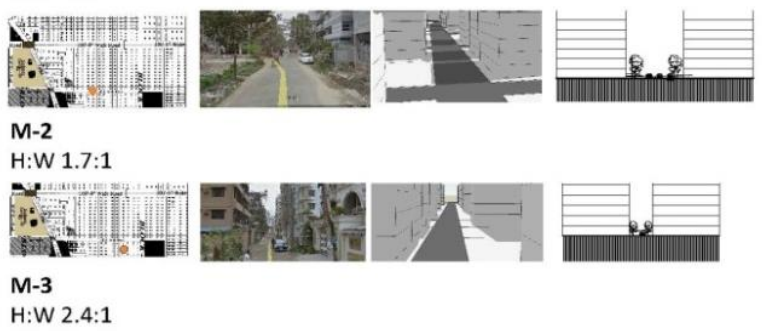

Fig. 10. . Selected study streets, Bashundhara R/A., Dhaka. 


\section{A. Appropriate building height and width ratio to create comfortable, shaded street and sense of enclosure}

Overall building height and road width ratio $(\mathrm{H} / \mathrm{W})$ of historical settlement is higher than the newly planned neighborhood. The average air temperature inside the shallow street canyon of Basundhara R/A is measured to be found higher than the historical street (figure 11). Here the temperature varies almost $2^{\circ} \mathrm{C}$ between historical and newly planned area. Moreover a significant temp difference is observed inside the same neighborhood of Basundhara due to the fact that the $\mathrm{H} / \mathrm{W}$ ratios of street canyons are relatively shallow and not consistent throughout development. It is observed that street with N-S orientation is cooler than W-S orientation. The higher the street canyon ratio $\mathrm{H}: \mathrm{W}=4: 1$ (historical streets $\mathrm{H}-1, \mathrm{H}-2$,) the more is the shadow on street. [17]

The average maximum humidity and corresponding wind speed are measured and found that historical streets are more humid with comparatively lower wind speed than the planned streets of Basundhara. The maximum RH and wind speed of planned streets are $89.83 \%$ and $2.53 \mathrm{~m} / \mathrm{s}$ whereas the historical streets are having $92.67 \%$ and $2.3 \mathrm{~m} / \mathrm{s}$ respectively. It is also observed that the wind speed condition of the historical streets are more consistent and various between $0.3-0.5 \mathrm{~m} / \mathrm{s}$ but the condition of new streets are having much higher inconsistency and varies around $0.61 \mathrm{~m} / \mathrm{s}$ among the streets during the survey period (figure 11).

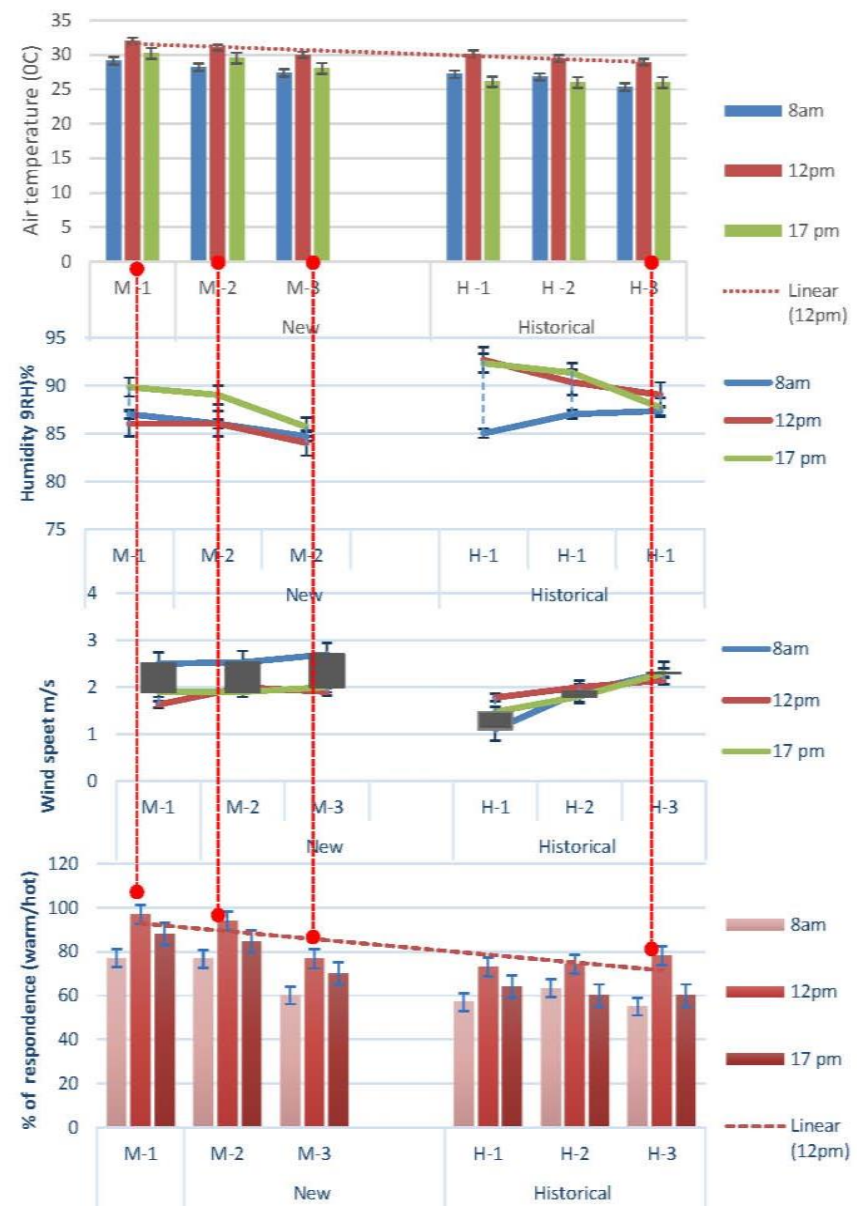

Fig. 11. Thermal comfort survey analysis for the study streets, Dhaka. Source: field survey
TABLE II. USER RESPONSE OF THERMAL COMFORT SENSATION (\%) IN STUDY STREETS, DHAKA

\begin{tabular}{|l|l|l|l|l|}
\hline $\begin{array}{l}\text { Warm/ } \\
\text { hot }\end{array}$ & streets & $\mathbf{8 a m}$ & $\mathbf{1 2} \mathbf{~ a m}$ & $\mathbf{1 7} \mathbf{p m}$ \\
\hline \multirow{3}{*}{ New } & $\mathrm{M}-1$ & $77 \%$ & $97 \%$ & $88 \%$ \\
\cline { 2 - 5 } & $\mathrm{M}-2$ & $76.6 \%$ & $94 \%$ & $84.6 \%$ \\
\cline { 2 - 5 } & $\mathrm{M}-3$ & $60 \%$ & $76.6 \%$ & $70.5 \%$ \\
\hline \multirow{3}{*}{ Historical } & $\mathrm{H}-1$ & $57 \%$ & $83 \%$ & $64 \%$ \\
\cline { 2 - 5 } & $\mathrm{H}-2$ & $63.3 \%$ & $84.3 \%$ & $60 \%$ \\
\cline { 2 - 5 } & $\mathrm{H}-3$ & $55 \%$ & $88 \%$ & $690 \%$ \\
\hline clothing & $0.4-0.5$ & 0.4 & 0.5 \\
\hline \multirow{2}{*}{ Activity (15-30 min) } & $\begin{array}{l}\text { Walking/ } \\
\text { standing }\end{array}$ & $\begin{array}{l}\text { Walking / } \\
\text { fast walking }\end{array}$ & $\begin{array}{l}\text { Walking/ } \\
\text { standing }\end{array}$ \\
\hline
\end{tabular}

To measure the comfort sensation, user responses are recorded the observed that a larger percentage $(80-90 \%)$ of respondents are not satisfied with thermal environment in newly planned streets compared to historical study streets (table 2).

In short the wind flow at the street level affected negatively by high $\mathrm{H} / \mathrm{W}$ ratio of historical settlement but this high density urban fabric help to lower the air temp through mutual shading and thus create a comfortable sensation for the pedestrian in historical street.

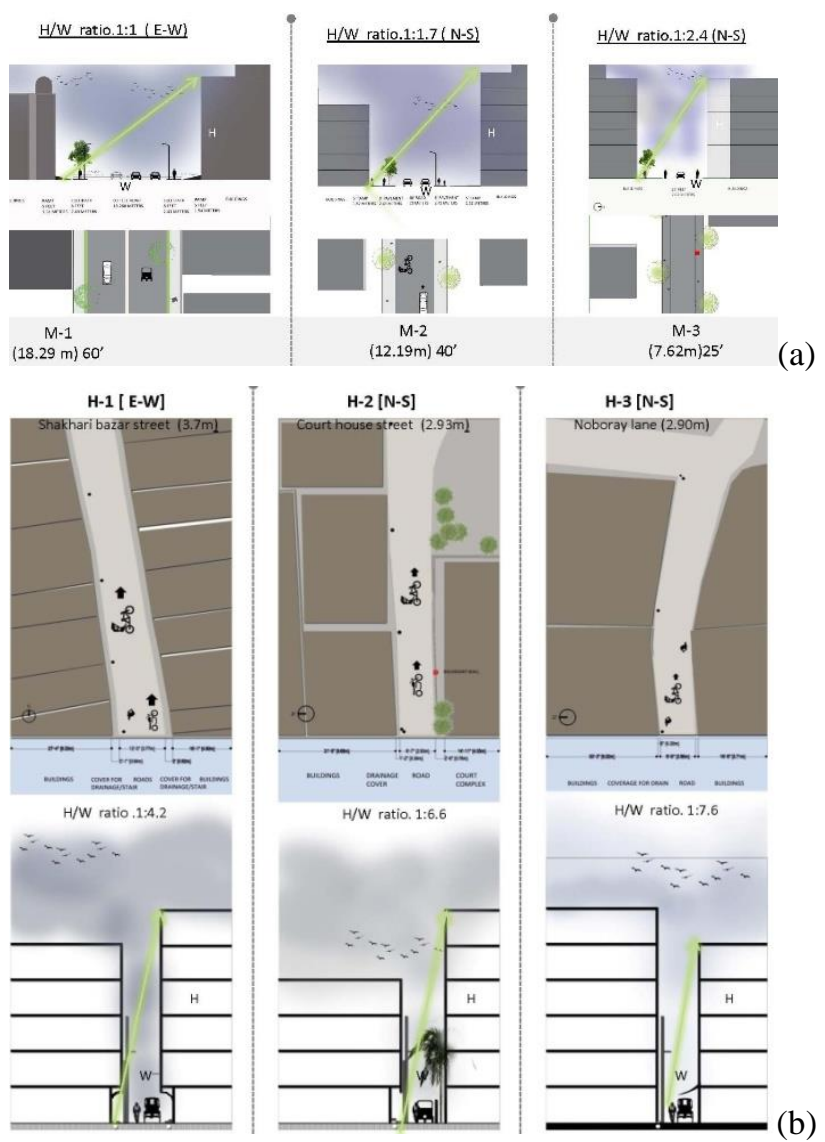

Fig. 12. (a). Selected study streets, Bashundhara R/A., Dhaka.

(b) Spatial enclosure and H/W ratio, study streets, Shakahari Bazar, Dhaka

Then again, to create a sense of spatial enclosure or partially shaded street $\mathrm{H}$ : W ratio should be minimum 1:1. Sense of enclosure can also be improved by planting trees or introducing similar barrier like colonnaded/arcade pathway. [18] 

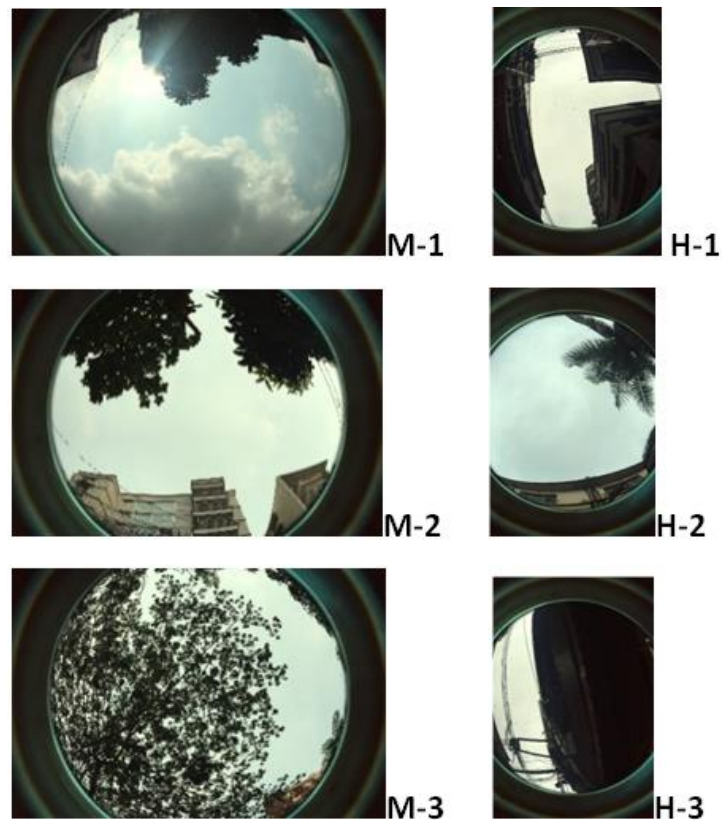

Fig. 13. Amount of visible sky from pedestrian level at three different canyons of the study streets

\section{B. Continuous and Active Building Frontage}

It is observed that planned residential area lacks street function, shops and activities. There is not even any street furniture (seating, dustbin, signage etc.). Historical street on the other hand, is commonly flanked by shop houses and mixed use functions; and along with communal functions and amenities this creates a continuous active building frontage. Such arrangement ensures availability of urban services within close proximity, within walking distance. Inclusion of the followings into the street fabric is, therefore, will positively influence walkability:

- Active building frontage

- Mixed use building with retail shop at the ground floor

- Social amenities

- Café and other utility shops etc

It is also suggested that community facilities should be located within 5 minute walking distance to make the neighborhood more pedestrian friendly. By utilizing existing vacant plots into Temporary Park, children's play area, badminton court, urban farming, seating zone for elderly, and some temporary kiosk for street vendors to sell vegetable or for tea coffee can be considered as immediate short term measure. These community facilities should be maintained or looked after by the local welfare society.
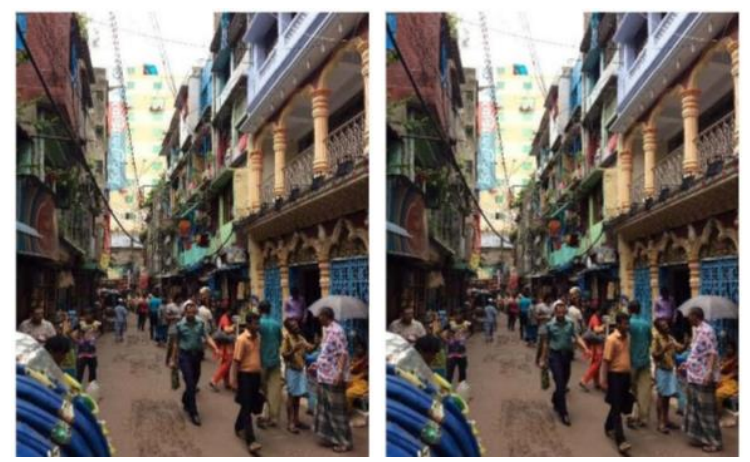

Fig. 14. Continuous active frontage, shakahari bazaar, Old Dhaka

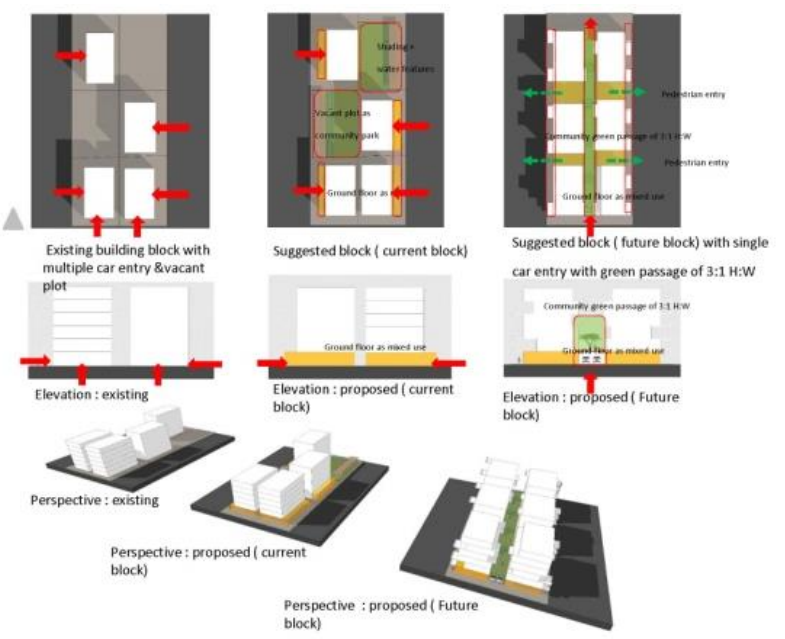

Fig. 15. Proposed elevated pathways within the setback of urban blocks, Bashundhara R/A.

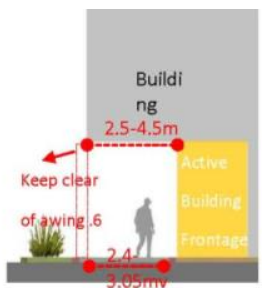

a) Cantilever

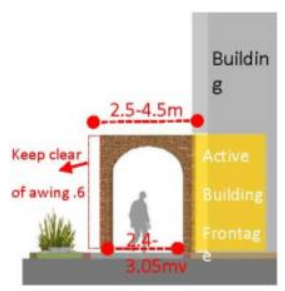

b) Arcade (clay brick)

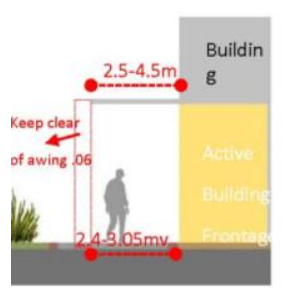

c) Over hang

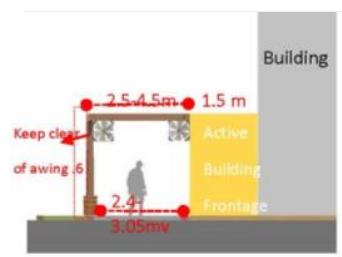

e) Pergola with local material

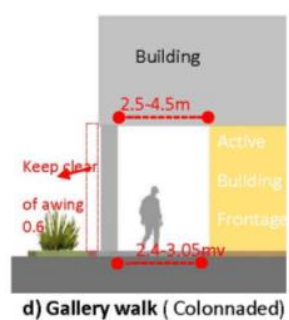

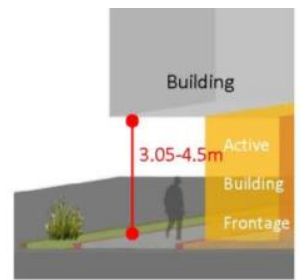

Perspective view

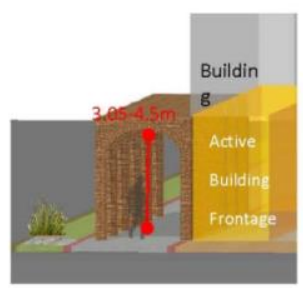

perspective view

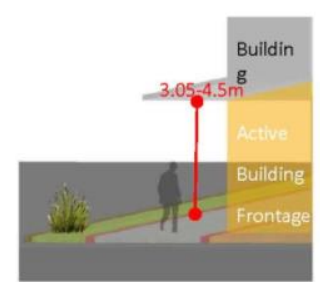

perspective view

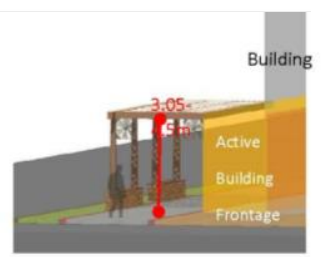

(wood, bamboo and mist fan)

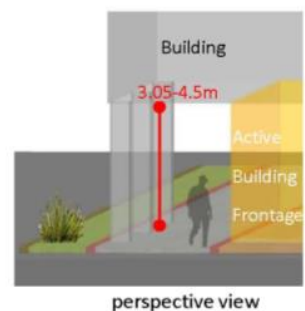

Fig. 16. Recommended shelter shading system for pedestrian pathways. 
Apart from sidewalks, a continuous dedicated pedestrian path can be introduced within the setback of existing urban blocks. A possible option for Basundhara R. A could be -

- Making a green passage in between the setback of two building is 2 nd level of the building considering $\mathrm{H}: \mathrm{W}$ $=3: 1$ and keep the 1st layer as parking and car entrance for the whole block, so instead of multiple car entrance there is 1 route for one block.

- Continuous ground floor as active building frontage that linked with the green passage with terrace as shading for the street and vegetation.

\section{Shelter Shading (archways, overhang, shadings and breezeways) on Pedestrian}

To ensure year round use and comfortable walking experience, walkway should be protected from both rain and sun. Therefore, shades and shelter should be a consideration while designing pedestrian pathway. Enclosure like archways/ arcade, building overhang, extension galleries, extended balcony, terrace of historical street fabric are found effective for mitigating heat and channeling wind. This type of enclosure also create a transitional space between outdoor and indoor and can be used as an extension of retail, café, utility shop, amenities etc. Design recommendations for shelter shading are as follows:

- Types and forms of shading elements may include-

$$
\begin{array}{ll}
\circ \text { Cantilevers } \\
\circ \text { Arcade } \\
\circ \text { Over hang } \\
\circ \text { Gallery walkway (colonnade) }
\end{array}
$$

○ Pergola shading preferably with local material for $\mathrm{N}-\mathrm{S}$ orientated street to allow air and sun to penetrate.

- The effective width of this arcaded way/shading/overhang should not be less than $2.5 \mathrm{~m}$ by keeping $0.6 \mathrm{~m}$ clear awing and 2 feet of curb.

- Adding mist fan, water features (fountain, rain water harvesting rain garden) will enhance calmer microclimate by passive cooling system.
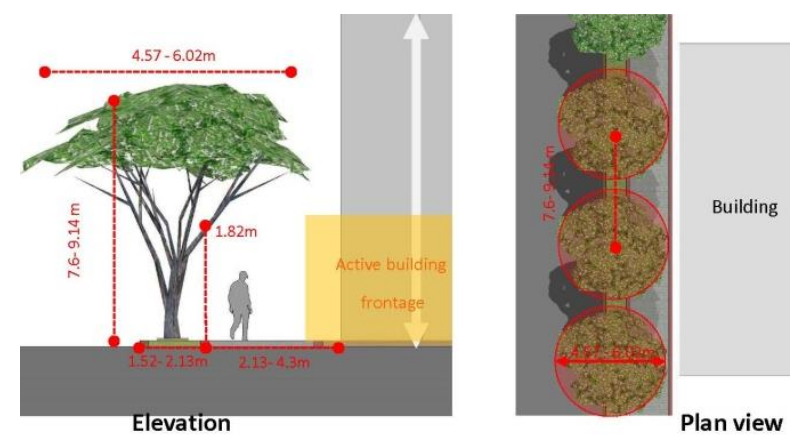

Fig. 17. Suggestion for shade trees beside walkways.

\section{Street-side plantation for the improvement of streetscape to ensure comfortable pedestrian}

Tree is one of the essential components to improve walkability, especially in high heat and humidity. It helps to reduce the air temperature and mean radiant temperature to a sufficient level. Plants canopy, vegetation reduces temperature of ground surfaces by 2 to 4 degree and thus considerably affect outdoor thermal environment. Selection of shade tree and plantation location is also crucial to ensure sky exposure along with wind flow at pedestrian level. Tentative height should be $4.5-6.02 \mathrm{~m}$ (at maturity) and average spacing from center to center is $7.6-9.14 \mathrm{~m}$ (average) with clear trunk of $1.82 \mathrm{~m}$ with shade canopy is suggested for shading [19]. For effective shading, trees should not be placed at the middle of the walkway; a separate green lane of min $1.5 \mathrm{~m}-2 \mathrm{~m}$ width between sidewalks and vehicular street performs better. The type of the tree is also very important but establishing such standard and detail requirements was beyond the scope of this research.

\section{CONCLUSION}

The measure of walkability is multi-faceted and involves physical (height-width ratio, vegetation, water features, orientation etc.) functional (amenities, infrastructure, safety etc.) and physiological aspects of urban streetscape. The study identifies three significant features $(\mathrm{H}: \mathrm{W}$ ratio, arcaded/ shaded street, continuous building frontage) from the historical urban street and suggests to integrate those features in newly planned streets in order to improve overall pedestrian environment thus walkability. It is observed that, in a subtropical context like Dhaka, high H/W ratio of historical street canyon keeps the street shadowed and cooler and thus comfortable for walking. The continuous active frontage of historical streetscape is another major reason for high walkability. Historic building features like arcade, overhang, colonnaded facades etc. also create road enclosures and ensures continuous use of walkways by protecting it from rain and hot summer sun.

In recent years, much attention has given to make the streets and pedestrians safer and aesthetically enjoyable in every context, but the focus, in future, should be extended to design climate and context specific streetscape that is responsive to human comfort and convenience correspondingly. The research findings and suggestions can be considered as a convenient reference for the urban designers, architects, and neighborhood development experts of the city with similar context.the PC, provides authors with most of the formatting specifications needed for preparing electronic versions of their papers. All standard paper components have been specified for three reasons: (1) ease of use when formatting individual papers, (2) automatic compliance to electronic requirements that facilitate the concurrent or later production of electronic products, and (3) conformity of style throughout a conference proceedings. Margins, column widths, line spacing, and type styles are built-in; examples of the type styles are provided throughout this document and are identified in italic type, within parentheses, following the example. Some components, such as multi-leveled equations, graphics, and tables are not prescribed, although the various table text styles are provided. The formatter will need to create these components, incorporating the applicable criteria that follow. 
Street Attributes
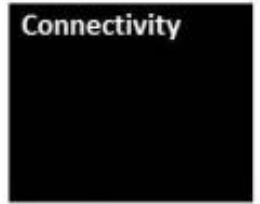

Amenities

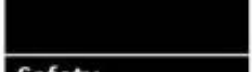

Safety
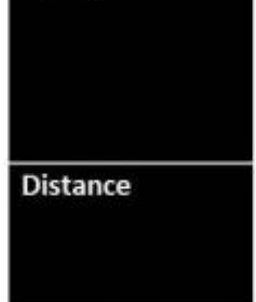

Infrastructure

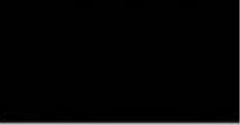

Mixed use and

density

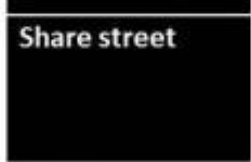

Thermal

Comfort

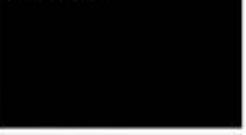

\section{Acoustic}

Comfort

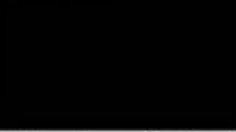

Visual comfort

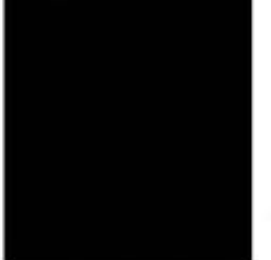

Olfactory comfort

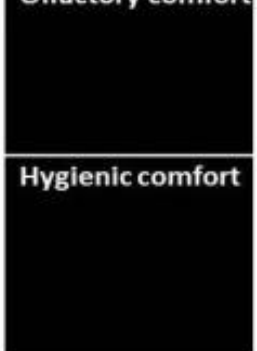

Design elements

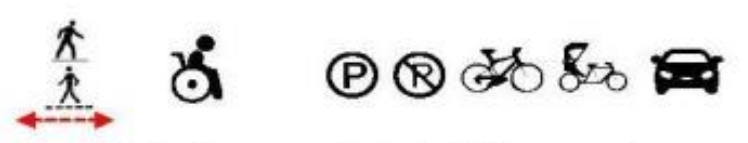

Cont. footpath Disable access Car/cycle/rickshaw park zone

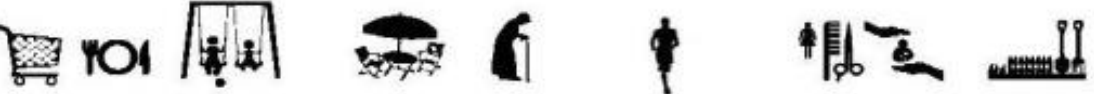

Shops, café, children play corner, seating, elderly corner, jogging trail, saloon, day care, urban farm

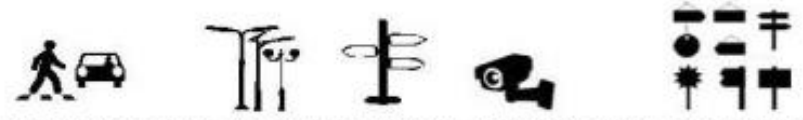

Sare street crossing, street light, signage, personal safety, information boarc

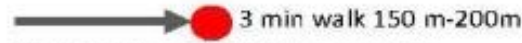

Direct route, accessible to amenities

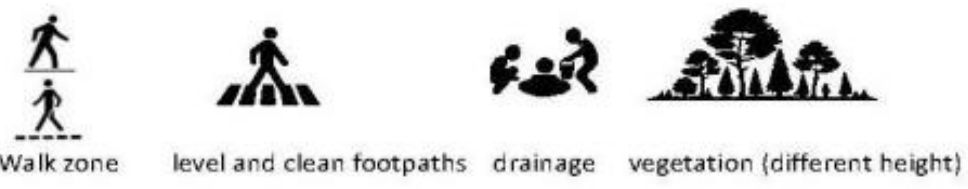

Walkzone level and clean footpaths drainage vegetation (different height)

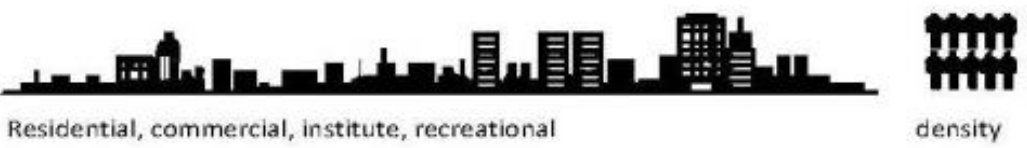

$$
\underset{\text { Pedestrian + acle +rickshawt }}{1100}
$$

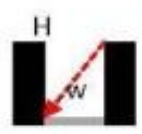

Shadowed canyon overhang

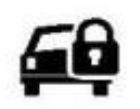

Slow traffic bufferfrom street remove parking

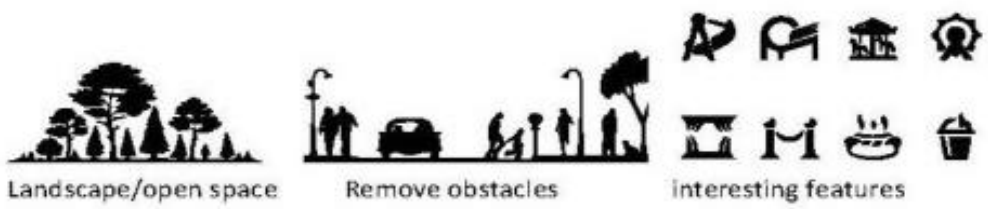

\section{눌}
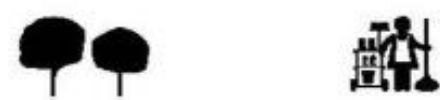

Dustbin well maintained vegetation clean walkways

\section{द्रे}

Proper drainage
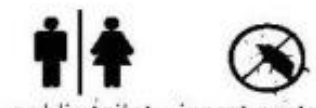

public toilet insect protraction

Fig. 18. Proposed checklist for designing walkable or pedestrian friendly streetscape. 


\section{REFERENCES}

[1] United Nations Department for Economic and Social Affairs, UN/DESA, "Monthly Briefing World Economic Situation and Prospects". Issue no. 22, 10 August, 2010; available at:http://www.un.org/.

[2] Talen, Emily, and Julia Koschinsky. "The Walkable Neighborhood: A Literature Review."International Journal of Sustainable Land Use and Urban Planning 1. No. ISSN 1927-8845 (2013),Pg- 42-63.

[3] San Schwartz Engineering, and AmericaWalks, comps. "Steps to A Walkable Community A Guide for Citizens, Planners, and Engineers." Vol. 1. New York: San Schwartz Engineering PLLC and America walks, 20121 available at: https://www.scribd.com.

[4] "Dhaka district", Wikipedia.; available at: https://en.wikipedia.org; Accessed September 29th, 2016

[5] The Urban Transport Policy (Draft- 8) The Strategic Transport Plan(Tstp,2004) For Dhaka The Louis Berger Group Inc Bangladesh Consultants Ltd,2004; available at: http://asialeds.org/.

[6] The survey report of Urban Transport Network Development Study (DHUTS), 2010; available at: http:/open_jicareport.jica.go.jp

[7] A statistical survey by "Walkability and Pedestrian Facilities in Asian Cities State and Issues, ADB sustainable Development", Working Paper Series,Issue no 17, 2011; available at: http://www.adb.org/; Accessed June 2, 2015.

[8] Walkable Community Inc. USA, non-profit org; available at: http://www.walkable.org; Accessed on September 29th, 2016

[9] Abley, Steve "Walkability Scoping Paper." Chartered Traffic and Transportation Engineer 3 ,February 2005.Pg : 5-18.. www.abley.com. Accessed January 14, 2015

[10] Bekele, S., Jones, I., and Rajamani, G. "Microclimate study of a city in hot and humid climate." In: Council on Tall Buildings and Urban Habitat 8th World Congress, 2008.

[11] Brisbane city centre master plan 2006, "A vision for the future of our city's centre.” Brisbane, Queensland, Australia. 2006

[12] Tropical Metropolitan,"Tropical mist system" ,2011; available at: http://www.tropicalmistsystems.biz; Accessed June 5, 2015.

[13] Ahmed, K. S. "Approaches to Bioclimatic Urban Design for the Tropics with Special Reference to Dhaka, Bangladesh." An Unpublished Doctoral Dissertation, Environment and Energy studies program, AA School of Architecture, London 1996. 33-105, 1995.

[14] Nayma Khan, and Farida Nilufar. "Spatial Logic of Morphological Transformation A Paradigm of Planned - Unplanned Areas in Dhaka city." 7th International Space Syntax Symposium, September 2009,Pg52-68.

[15] RAJUK (Rajdhani Unnoyon kortipokkho), Detailed Area Plan (DAP). 2010. available at: http://www.rajukdhaka.gov.bd; Accessed May 3 , 2015

[16] Official website,Bashundhra group,2014; available at: http://www.bashundharagroup.com; http://www.ewpd.com.bd/; Accessed May 21,2015

[17] Institute of Transportation Engineers, comp. Design Walkable Urban Thoroughfares: A Context Sensitive Approach. Vol-1. Publication No. RP-036A,Printed in the United States of America: Institute of Transportation Engineers, West Washington, DC 20005-3438 USA .ITE on the Web: www.ite.org, 2010.Accessed June 14,2015.

[18] Lin, Tzu-Ping, Richard De Dear, and Ruey-Lung Hwang. "Effect of Thermal Adaptation on Seasonal Outdoor Thermal Comfort." International Journal of Climatology Int. J. Climate. Vol. 31, no. 2 (2011): 302-12. doi:10.1002/joc. 2120

[19] DeVau, M., "Strategies to Address the Climatic Barriers to Walkable, Transit-Oriented Communities in Florida", Goergia institute of
Technology School of City and regional Planning, Master Thesis, 46. 2011

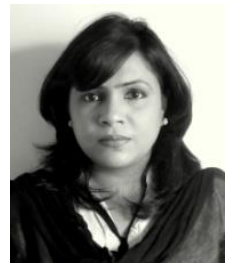

Farzana Siddiqua is an academic researcher and lecturer in the Department of Architecture, American International University Bangladesh (AIUB) since 2009.Her bachelor of Architecture degree(B.Arch) is from Bangladesh University of Engineering and Technology (BUET) and she had her Master of Urban Design (MUD)from the University of Hong

Kong (HKU) under the Asian Development Bank-Japan Scholarship Program (ADB-JSP)in 2015. Throughout the las semester of her masters she was doing her masters on 'Measuring Impacts of "Outdoor Comfort" on "Walkability" in a warm humid city: a perspective from New and Historical streets cape in the residential area of Dhaka, Bangladesh' which was awarded by the Hong Kong Institute of Surveyors (HKIS). Her main research interests are on urban design, outdoor comfort, walkability, sustainability.

Saimum Kabir is the Assistant Professor of Department of Architecture, American International University Bangladesh (AIUB) and has been involved in teaching since 2008. He had completed his B.Arch and M.Arch program from Bangladesh University of Engineering and Technology (BUET). He did his second master in MaHS (Master of Human settlement) program from KU Leuven, Belgium in 2013.

His special interest is in Human settlement and sustainability. Several of his research paper has been published on national and international journals and conference proceeding titled, A study of Thermal Comfort in Outdoor Urban Space in respect to Increasing Building Height in Dhaka Climate Change Vulnerable Community: A Case of Coastal Bangladesh, Towards sustainable rural development: an investigation on mud and clay based material, its potential and appropriateness, Vulnerability and Adaptation in Settlement pattern: A Case of Water Logged Village in Keshabpur etc.

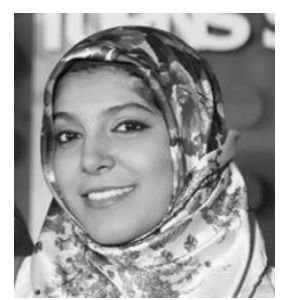

Mania Tahsina Taher is an Assistant Professor of Department of Architecture, American International UniversityBangladesh (AIUB). She received her B.Arch from Bangladesh University of Engineering and Technology (BUET) in 2008, afterwards received MS.AUD from Columbia University, New York, USA. She has been teaching in AIUB for 6.5 years Mania's research interest focuses on the housing settlement pattern and land-use study of metropolitan cities and their fringe areas, study of urban human environment and how people participate, history of urban settlements. 